\title{
河川水，水道水及び加熱した水道水中の多環芳香族炭化水素
}

$\begin{array}{llll}\text { 高 橋 } & \text { 保 } & \text { 雄* } & \text { 小野寺 祐 } \text { 夫** }^{*} \\ \text { 森 } & \text { 田 昌 敏*** } & \text { 寺尾 良 } \text { 保 }^{\dagger}\end{array}$

\section{Determination of Polynuclear Aromatic Hydrocarbons Concentration in River Water, Tap Water and Heated Tap Water Using Kettle, Electric Pot and its Device}

\author{
Yasuo TAKAHASHI", Sukeo ONODERA*, \\ Masatoshi MORITA $^{\text {**** }}$ and Yoshiyasu TERAO \\ * Tokyo Metropolitan Institute of Public Health, Hyakunincho 3-24-1, Shinjuku-ku, Tokyo 169-0073, Japan \\ * Faculty of Pharmaceutical Science, Tokyo University of Science, Yamazaki 2641, Noda-shi, Tiba 278-8510, Japan \\ $* * *$ Faculty of Agriculture, Department of Environmental Conservation, Ehime University, Tarumi 3-5-7, Matsuyama 790-8566, \\ Japan \\ $\dagger$ Graduate School of Nutritional and Environmental Sciences, University of Shizuoka, Yada 52-1, Shizuoka, Shizuoka 422-8526, Japan
}

\begin{abstract}
In this study, we determined the concentrations of 29 polynuclear aromatic hydrocarbons (PAHs) and related oxidants (four kinds) in river, drinking and heated water samples. The composition of PAHs in drinking water differed from that of PAHs in river water, and the concentrations of dibenzofuran, fluorene, 9-fluorenone and antraquinone in drinking water were higher than those in river water. The total concentration of PAHs in drinking water in the neighborhood around a water purification plant was the same as that of PAHs in river water (the main stream). However, the total concentration of PAHs in drinking water supplied from water purification plants was higher in distant areas than in the neighborhood around the water plant. From to the concentrations and detection frequencies of PAHs in drinking water, those of dibenzofuran, fluorene, 9-fluorenone and antraquinone were the highest, whereas the PAHs showing the second highest concentrations and detection frequencies were naphthalene, biphenyl and phenanthrene. Furthermore, the total concentration of PAHs peaked during summer at $200-300 \mathrm{ng} \cdot l^{-1}$ and showed a trough at $10-30 \mathrm{ng} \cdot l^{\text {-1 }}$. The total concentration of PAHs in drinking water collected from a specific district in the Tokyo metropolitan area was about 200 $\mathrm{ng} \cdot l^{-1}$ during summer. Compared with unheated drinking water, the concentrations of individual PAHs, total PAHs and PAH oxidation products are decreased in drinking water that has been heated using an electric pot or a kettle. The daily intakes of total PAHs are estimated to be 20-60 ng during winter and 200-600 ng during summer for people who drink only $2000 \mathrm{ml}$ of tap water, and 15-45 ng during winter and 150-450 ng during summer for people who drink $1000 \mathrm{ml}$ of tap water and $1000 \mathrm{ml}$ of heated water.
\end{abstract}

Key words : polynuclear aromatic hydrocarbon, river water, drinking water, heated drinking water

1.はじめに

多環芳香族炭化水素(PAHs) は水環境の污染物質の一 つであり，人体に有害な影響を及ぼす可能性が指摘され ている ${ }^{1 \sim 3)}$ 。その為，国際がん研究機関 (IARC) はPAHs 7 種類を分類評価 2 , PAHs 3 種類を分類評価 3 に定め,
アメリカ環境保護庁 (EPA)はPAHs16種類を優先污染物 質に設定している。

水道本管の内面叙装郕として，アメリカではアスファ ルト等，イギリス，日本ではコールタール等が使用され ている。アスファルト，コールタール中にPAHsが含 有していることから，1980年前後に水道水中のPAHs

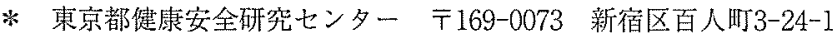

** 東京理科大学薬学部 T278-8510 野田市山崎2641

*** 愛媛大学農学部 $7790-8566$ 松山市樽味3-5-7

$\dagger$ 静岡県立大学大学院生活仵康科学研究科 $\bar{T} 422-8526$ 静岡市谷田52-1 
が測定されてきた ルエポキシ樹脂塗料の内面㬁装等への使用中止を決め, 新規に埋設する水道本管の内面叙装郕にコールタールが 使用できなくなった。そして，世界保健機関(WHO)が PAHs を検討課題としたことから，厚生労働省は研究班 を立ち上げ，1997年 4 月より2000年 3 月まで調査研究を 行ってきた。

そこで，著者らも PAHs(29種類)の溶媒抽出法の一斉 分析法を確立し，その一斉分析法を用いて河川水及び給 水栓水中の PAHs 濃度, 水道水中の PAHs 濃度の季節 変動, 都内の水道水中のPAHs 濃度, 加熱した水道水 中の PAHs 濃度を定量L, PAHs 污染由来と污染実態 を把握し, 水道水の放用によるPAHs 摄取量を検討し, それぞれの知見を得たので報告する。

\section{2. 実験方法}

\section{1 試薬類}

Table 2 のPAHs38種類と内部標準物質のナフタレン

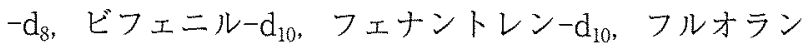
テン $-\mathrm{d}_{10}$ ，クリセン $-\mathrm{d}_{12} の 5$ 種類は和光純薬(株)，関東 化学(株), 東京化成(株)，ジーエルサイエンス(株)の標 準品または試薬特級を用いた。

PAHs 標準原液 $1,000 \mathrm{mg} \cdot l^{-1}$ ，また，内部標準原液 100 $\mathrm{mg} \cdot l^{-1}$ は無極性溶媒のへキサンに溶解させた。しかし， 溶解しない場合には，ジクロロメタン，アセトン，メ夕 ノールを混合，あるいは，それら溶媒に単独で溶解させ た。また, $1.000 \mathrm{mg} \cdot l^{-1} て ゙$ 溶解しない $\mathrm{PAHs}$ 標準原液は $250 \mathrm{mg} \cdot l^{-1}$ ，あるいは100mg $l^{-1}$ に調製した。PAHs 混 合標準液, 内部混合標準液はジクロロメタンで，添加回 収用のPAHs 混合標準液はメタノールで随時調製した。 標準原液, 混合標準液は褐色の保存瓶に入れ， $-20^{\circ} \mathrm{C}$ で 保管にした。

ジクロロメタン，ヘキサン，アセトン，メタノール， 塩化ナトリウムは和光純薬(株)の残留農薬試験用, 塩酸 は和光純薬(秼)の有害金属測定用，アスコルビン酸は和 光純薬(株)の特級を使用した。ミネラルウォーターはボ ルヴィック，大清水，天然水を用いた。

\section{2 採水場所 $\cdot$ 時期等}

河川水と水道水中のPAHs 濃度では，Fig. 1 に示した 金町浄水場の取水口加ら上流に向けて約 $25 \mathrm{~km}$ の江戸川 8 地点 (本流 6 地点，支流 2 地点) と，金町浄水場加約 $1 \mathrm{Km}$ 離れた金町公園の給水栓水，及び荒川を主に原水 とした当職場(健康安全研究センター)の蛇口水を，2003 年6月30日，2004年 7 月15日，2005年 7 月 4 日に採水し た。

PAHs 濃度の季節変動では，当職場の蛇口水を2003年 10月～2004年 9 月まで, 計30回採水した。

都内特別区のPAHs 濃度では, Fig. 1 に示した蛇口水 10尔所 $(A \sim J)$ を2004年 8 月に採水した。

加熱した水道水中のPAHs 濃度では，大型ボイラー では2004年 9 月 $6 ， 13 ， 21$ 日の 3 回，電気ポット，やか んでは2005年 7 月 1 日，8月 4，5日の 3 回，当職場の 蛇口水とその沸かした水を用いた。

な抢，河川水の水温は国土交通省の水文水質データの 水質一覧表, 気温は気像庁の東京都の気温デー夕を用い た。

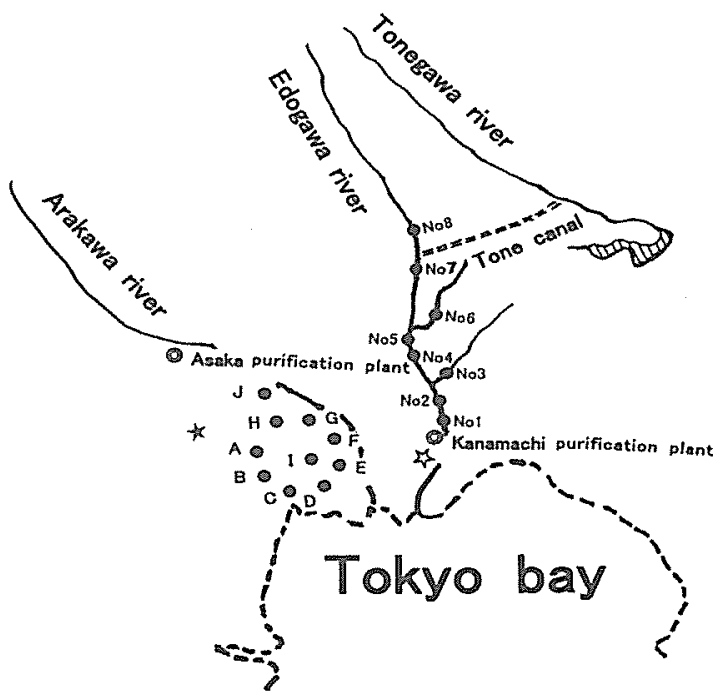

Fig. 1 Sampling sites at the Edogawa river and specific district in the Tokyo metropolitan

The Edogawa river :

- No.1 ; Intake of Kanamachi purification plant

- No.2; Akagome No.3; Akagome bridge

No.4; Kogazaki No.5; Syusui

No.6; Syusui bridge No.7 ; Nagareyama bridge

- No. 8 ; Noda bridge

Specific district :

A ; Shinzyuku station B ; Sibuya station

- C; Meguro station D; Hamamatutyo station

- E; Tokyo station $\mathrm{F}$; Ueno station

- G; Tabata station $\bigcirc \mathrm{H}$; Ikebukuro station

O I Ochanomizu station $\mathrm{J}$; Akabane station

*; Tokyometropolitan research laboratory of public health

is ; Kanamachi park

Table 1 Apparatus and operational conditions for GC/MS

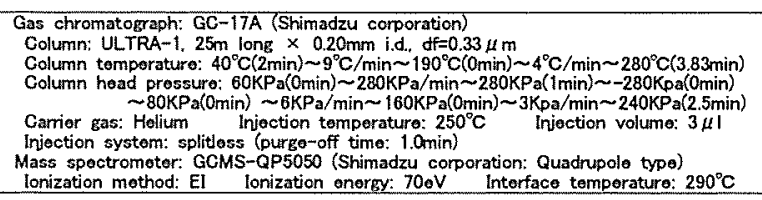

\section{3 装置及び機器の測定条件}

PAHs 濃度測定は島津製作所社製 GC-17A 型の GC 及 び同社製 QP5050型の MS を使用して，Table 1 の測定条 件で行った。なお，定量イオンは開裂ピークでなく，そ れぞれPAHsの分子量ピークの質量数を用いて，定量 を行った。

\section{4 定量方法}

試料水 $1,000 \mathrm{~m} l$ に塩化ナトリウム $50 \mathrm{~g}$ 添加し, ジクロ ロメタン $100 \mathrm{ml}$ で抽出を 2 回行った。このジクロロメタ ン抽出液を $0.25 \mathrm{~m} l$ に濃縮し, 更に内部標準液を一定量 添加後，それぞれPAHsをGC/MS-SIM で定量した。

\section{3. 結果と考察}

\subsection{PAHs $の$ 定量下限值と回収率等}

試料水中のPAHs 分析法は主に濃縮と分離・検出の 組み合わせである。濃縮方法として溶媒抽出法と固相抽 出法があり，分離・検出法として GC/MS-SIM 法と HPLC/蛍光法があり，既に多数報告されている ${ }^{11 \sim 14)}$ 。 
Table 2 Determination limits, recoveries and coefficients of variation of polynuclear aromatic hydrocarbons in water

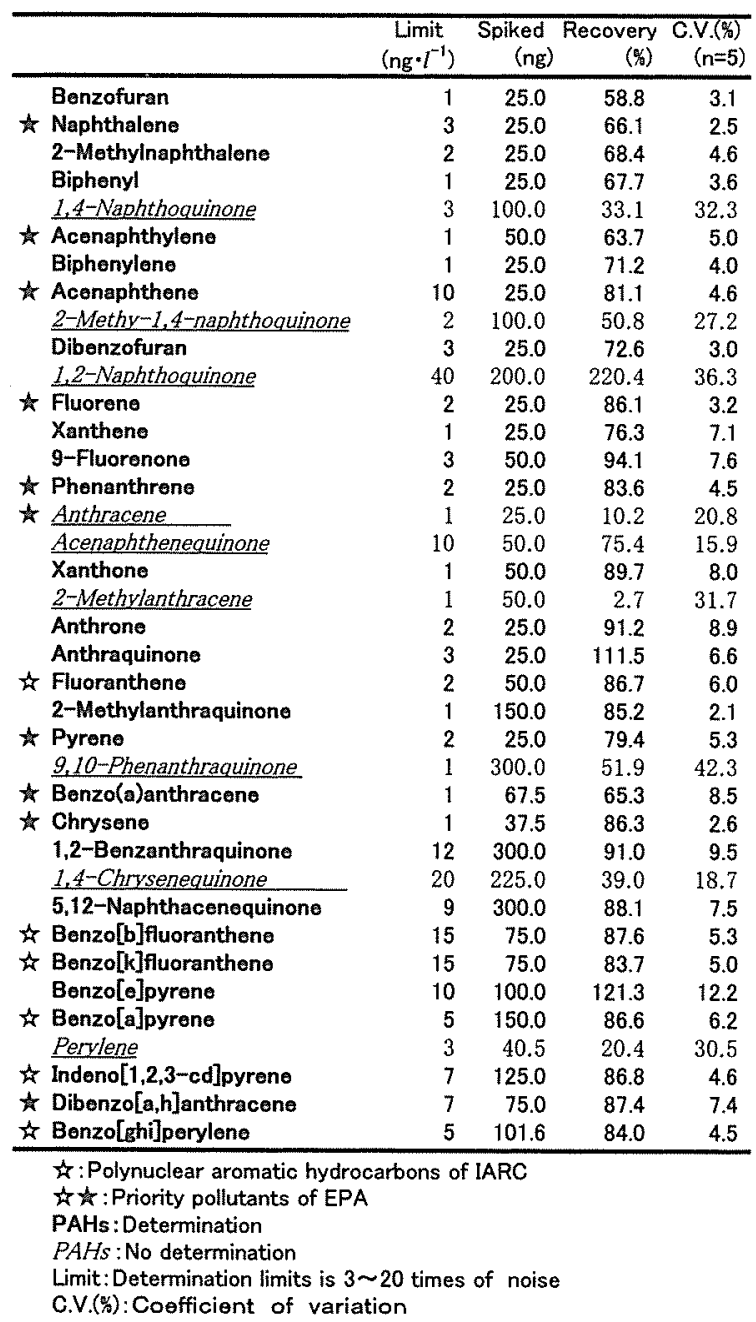

測定対象としているPAHsは主に縮合環が 3 環〜 5 環 であるPAHsで，多くの場合 IARC 指定のPAHs(10種 類)，あるいはEPA 設定のPAHs(16物質)である。しか し，著者らは Table 2 に示した縮合環が 2 環〜 5 環であ るPAHs を対象として, EPAのPAHs16種類，検出例 のあるPAHs とその PAHs 酸化体(キノン体 $)^{4 \sim 10)}$, 合計 38種類を溶媒抽出(ヘキサンとジクロロメタン)と GC/ MS-SIM の組み合わせによる一斉分析法を検討した。

その結果，今回の GC/MS-SIM では, Table 2 のベン ゾフランからフルオランテンまでの PAHsはヘキサン 抽出ではテーリングし，ジクロロメタン抽出ではテーリ ングしなかった。そこで, ジクロロメタン抽出 - GC/ MS-SIM を採用することにした。なお，クリセンはト リフェニレン, ベンゾ[a]アントラセンは1,2-ベンゾア ントラセンと分離不十分であったが，クリセン，ベンゾ [a]アントラセンとして測定した。

Table 2 より，アントラセン, メチルアントラセン, ペリレンは回収率が非常に小さく，変動係数は大きかっ た。また1,4-ナフトキノン,2-メチル-1,4-ナフトキノン, 1,2-ナフトキノン，アセナフテンキノン，9.10-フェナン トラキノン，1.4-クリセンキノンの PAHs 酸化体 6 種類 は変動係数が大きく，回収率は大きいか，あるいは小さ かった。それ以外のPAHs25種類とPAHs 酸化体 4 種
類 (Table 2 中の太字PAHs で表示), 合計29種類は回収率, 変動係数が良好で, 定量下限值が $1 \sim 15 \mathrm{ng} \cdot l^{-1}$ (多くは $\left.1 \sim 2 \mathrm{ng} \cdot l^{-1}\right)$ であった。Table 2 の回収率，変動保数は ミネラルウォーターを用いたデータであるが，河川水で は浮遊物質が肉眼でほとんど見えない試料水，水道水で は残留塩素を等量で除去した試料水もほほ同じ值であっ た。太字で書かれたPAHs29種類はジクロロメタン抽出 - GC/MS-SIM 法の一斉分析で可能であり, 今回, この PAHs25種類と PAHs 酸化体 4 種類を分析対象とした。 なお, PAHs 酸化体の定量イオンは分子量イオンを用い たので，定量下限值は高くなった。また，今回の測定結 果は，回収率による補正を行っていない。

アントラセン(メチルアントラセンも含め), ペリレン は塩素処理により，容易に分解し，一部酸化体になり ${ }^{15)}$, 水道水中から検出されない占。これら PAHsはジクロロ メタン抽出(極性溶媒)では, 一部分解し, 回収率が低下 し，また変動係数も大きくなったと推測される。一方， ヘキサン抽出(無極性溶媒)では分解されず，回収率は約 $70 \%$ となり, 変動係数も約 $2 \%$ と小さかった。

今後，上記の変動係数が大きく, 回収率は大きいか, あるいは小方かったPAHs 酸化体 ( 6 種類)の分析法を 検討し, 更に9-フルオレノン, アントラキノン, メチル アントラキノン，1.2-ベンズアントラキノン，ナフタセ ンキノンを含めたPAHs 酸化体の一斉分析法を確立寸 ることが必要であると考えている。

\section{2 河川水及び水道水中のPAHs 濃度}

Fig. 2 は2003年 6 月30日，2004年 7 月15日，2005年 7 月 4 日に調査した水道原水である江戸川の本流 6 地点, 支流 2 地点中の平均 PAHs 濃度である。また, 江戸川 を浄水処理している金町浄水場近陊の金町公園の給水栓
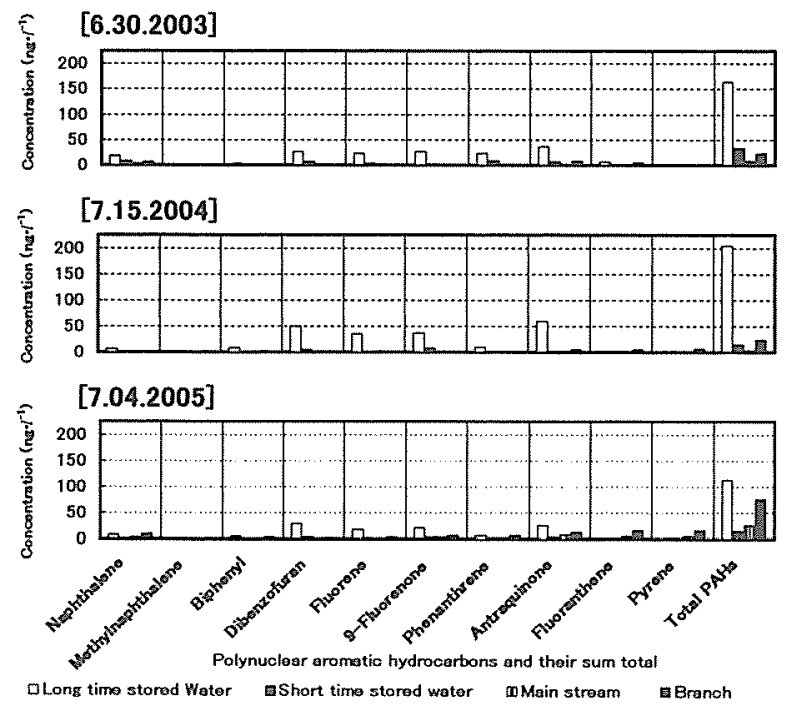

Fig. 2 The concentrations of polynuclear aromatic hydrocarbons in tap water and river water

Long time stored water: Water supplies at a far place (Our laboratory) serviced from water purification plant

Short time stored water : Water supplies at a near place (Kanamachi park) serviced from water purification plant

Main stream : Main stream of the Edogawa river Branch : Branch of the Edogawa river 
水と，江戸川の水質と類似した河川水である荒川を浄水 処理した後，浄水場から遠く離れた水道水(当職場の蛇 口水)中の PAHs 濃度である。

Fig. 2より，2003年6月30日，2004年 7 月15日の河川 水中から検出したPAHsはナフタレン, メチルナフ夕 レン, ビフェニル, フルオレン, フェナントレン, アン トラキノン，フルオランテン，ピレンであり，その個多 の PAHs 濃度は不検出一数 ng· $l^{-1}$ であり，合計 PAHs

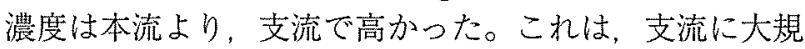
模の団地があり，団地の水道排水が河川水に流入してい ることに起因している可能性がある。そして, PAHsは 雨が降ると，アスファルト舗装道路等を経由して河川に 流れ込む ${ }^{16)} の て ゙ ， 2005$ 年 7 月4日は早朝から雨が降って いたので，2003年6月30日，2004年 7 月15日に比べ個々 のPAHs 濃度が高く，ジベンゾフラン，9-フルオレ， ンも検出され，更に，アントラセン，ベンゾ[a]ピレン も検出された。

水道水中から検出した個々のPAHs 濃度は数 $\mathrm{ng} \cdot l^{-1}$ 〜数10ng $\cdot l^{-1}$ で，主にナフタレン，ジベンゾフラン，フ ルオレン, 9-フルオレノン, フェナントレン, アントラ キノンであった。金町浄水場近隣の金町公園の給水栓水 の合計 PAHs 濃度は10 30ng $l^{-1}$ であり，浄水場から離 れた当職場の水道水中の合計 PAHs 濃度は100〜 200ng l゙であった。

PAHsは浄水処理の凝集沈殿処理により，䀣濁態は $50 \%$ 除去されるが，溶存態は殆ど除去されないと報告さ れている ${ }^{16,17)}$ 。しかし，浄水場近隣である金町公園給水 栓水中の PAHs は江戸川本流中のPAHsの種類と PAHs 比率パターンは異なり，PAHs 濃度が高くなるこ
とが認められた。また，浄水場から離れた(水道本管と 長く接触した) 当職場の水道水中の PAHs の濃度は飛躍 的に高加た。

これら PAHs が水道水中から検出する原因は，水道 本管の内面塗装剂，コールタール70\%含有のタールエポ キシ樹脂に起因している と考えられる。給水管の内面 塗装剤，タールエポキシ樹脂由来も考元られるが，東京 都では水道メーターまでの給水管の多くはタールエポキ シ樹脂を使用していないことから，給水管由来は非常に 小さいと考えられる。また, 水道水中の残留塩素により， 水道本管内面のコールタール表面は防護効果を発揮する 生物膜をつくらないので, PAHsが更に溶出しやす $w^{18,19)}$ 。

アントラキノン，9-フルオレノンはタールエポキシ樹 脂から溶出したアントラセン，フルオレンが水道水中の 残留篮素と反応して, 生成した酸化体である ${ }^{15)}$ 。従って, フェナントレン，アセナフチレン，4環以上のPAHs(ベ ンゾ(a)アントラセン，ピレン，フルオランテン等)も水 道水中に溶存すれば，残留塩素と反応し，酸化体が生成 されている可能性がある。しかし，今回著者らが確立し た一斉分析法では，これら PAHs 酸化体は分析できな 加た。

\section{3 水道水中のPAHs 濃度の季節変動}

Fig. 3，Fig. 4 は 1 年間モニタリングした当職場の蛇口 水中の合計 PAHs 濃度と河川(水道原水)の水温, 検出 した個々のPAHs 濃度である。蛇口水中の合計した

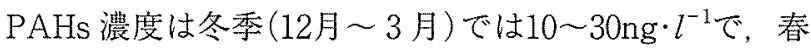
季で徐々に増加し，夏季( 6 月〜8月)では200～300ng. $l^{-1}$ になり, 秋季で減少している。検出したPAHsの内,

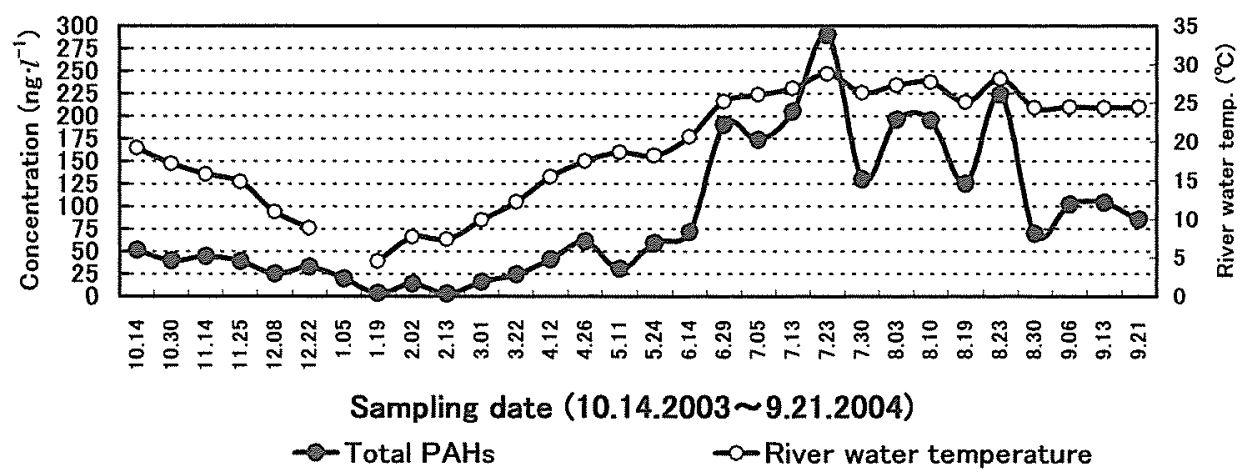

Fig. 3 Total Concentrations of polynuclear aromatic hydrocarbons in tap water at our laboratory during October $2003 \sim$ September 2004

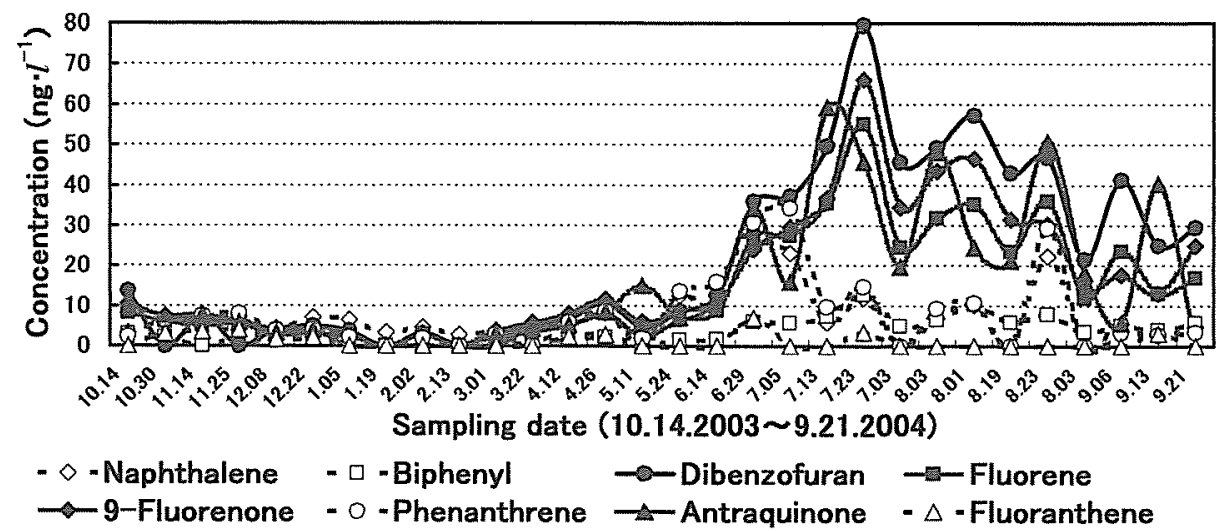

Fig. 4 The concentrations of polynuclear aromatic hydrocarbons in tap water at our laboratory during October $2003 \sim$ September 2004 
濃度・検出頻度が共に高いPAHs はベンゾフラン，フル オレン，9-フルオレノン，アントラキノンであり，次ぎ に濃度・蚞出頻度が高いPAHs はナフタレン，ビフェ ニル，フェナントレンであり，これら PAHs 濃度は夏 季に数十 $\mathrm{ng} \cdot l^{-1}$ で，冬季に数 $\mathrm{ng} \cdot l^{-1}$ で，合計 PAHs と 同様の季節変動を示している。濃度・検出頻度が共に小 さいPAHsとして, フルオランテン, 更に小さいPAHs として，メチルナフタレン，ピレンがある。白石らも， つくば市の水道水からほぼ同種のPAHs 検出し, PAHs 濃度も著者らの検出したPAHs 濃度範囲内であっ た8)。また，小野寺らは都内の一部PAHs 酸化体濃度を 測定しているが, 著者らの検出したPAHs 酸化体の濃 度籁囲内であっだ歺。

当職場の蛇口水は，浄水場から受水槽に入るまでに要 する時間，さらに受水槽＋高置水槽を経由するのに要す る時間は計約1.5日であると考えている。当職場の蛇口 に届いた水道水が水道本管に入る日時は採水日より 1.5 日前と考えている。水道本管中の水温データがないので, 河川水の水温(国土交通省の公開デー夕)，あるいは東京 都の気温(気象庁の公開データ)を用いて検討した。その 結果, PAHs 濃度と採水日の1.5日前の水温, 2 日前の 気温との相関係数は, 共に0.85であった。水温と気温の 相関係数は0.99であった。

この相関係数より, PAHs 濃度の季節変動は, 水温(気 温)に大さく影響されていると考えられる。

\section{4 都内の水道水中の PAHs 濃度}

夏季にPAHs 濃度が最高值になるので，東京都特別 区の8月における蛇口水中のPAHs 濃度を調査した。

Table 3 は，採水10地点 (Fig. 1 の J)の 8 月に採水し た水道水中の主な PAHs 濃度と合計PAHs 濃度である。

都内の特別区内の合計 PAHs 濃度は平均 $200 \mathrm{ng} \cdot l^{-1}$ (約 $\left.100 \sim 300 \mathrm{ng} \cdot l^{-1}\right)$ で, 個々のPAHs 濃度の内, ベンゾフ ラン, フルオレン, 9-フルオレノン, アントラキノン, フェナントレンは数十 $\mathrm{ng} \cdot l^{-1}$, ナフタレン, ビフェニル, フルオランテンは数 ng $\cdot l^{-1} て ゙$ 検出されていた。

今回調查した特別区内では，タールエポキシ樹脂を コーティングした水道本管は埋設されてから，数十年経 過しているが, PAHsは現在も溶出していると考えられ る。そして，採水地点の PAHs 濃度の差は水道本管の夕一 ルエポキシ樹脂と水道水との接触時間及び水温, 水道本 管の埋設年数, 水道原水の水質が異なることに由来する と推測している。

\section{5 加熱した水道水中のPAHs 濃度}

水道水を直接飲用する人は約 $25 \%$ あ゙あと言われてい る。残り $75 \%$ の人達は水道水を沸かしたり, 浄水器を通

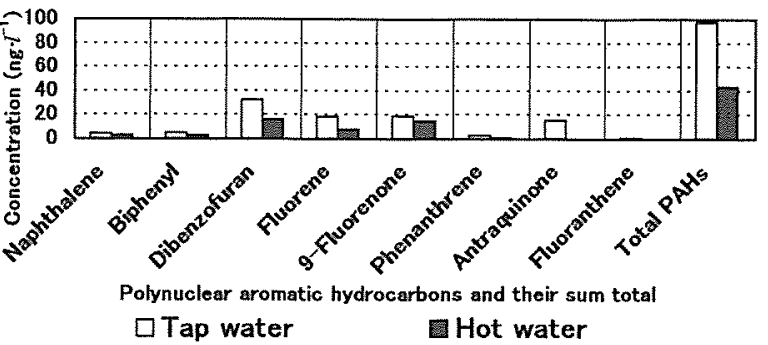

Fig. 5 Concentration of polynuclear aromatic hydrocarbons in tap water and in hot water heated using - Iarge sized boiler

したり、ミネラルウォーターを飲用している201。そこで, 加㷦した水道水中のPAHsの組成変化とPAHs 濃度変 化を調べた。

Fig. 5 は 3 回検查した大型ボイラーに使用した水道水 と給湯水中の平均 PAHs 濃度である。給湯水中の合計 PAHs 漂度は使用した水道水の合計 PAHs 濃度の約 $50 \%$ に減少していた。水道水から検出しているナフタレン， ベンゾフラン, フルオレン, 9-フルオレノン, フェナン トレン濃度も給湯水中で大幅に減少し、アントラキノン， フルオランテン濃度は共に不検出になった。

Fig. 6 は3 回検査した電気ポット，やかんで沸かすの に用いた水道水と沸かした水道水中の平均 PAHs 濃度 である。電気ポット，やかんで沸かした水道水中の合計 PAHs 濃度は使用した水道水の合計 PAHs 濃度の約 40\%，約30\%に減少していた。

電気ポット，やかんで沸かした水道水中のナフタレン 濃度は共に不検出であった。そして，電気ポットで沸か した水道水中のビフェニル, ベンゾフラン,フルオレン， 9ーフルオレノン,アントラキノン濃度は減少し, 電気ポッ

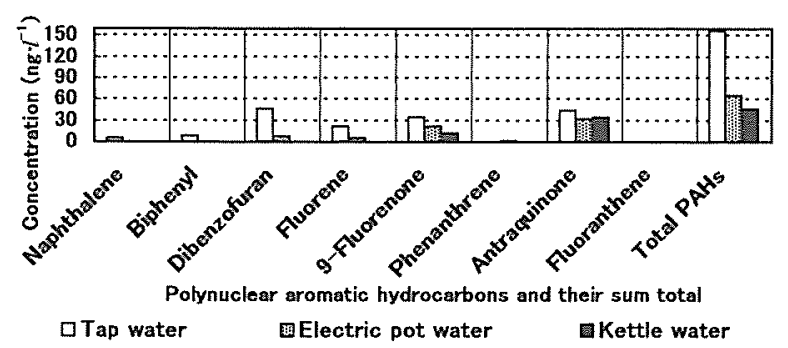

Fig. 6 Concentration of polynuclear aromatic hydrocarbons in tap water, in electric pot water heated using electric pot ant in kettle heated using kettle

Tap water : Tap water before heating

Electric pot water : Tap water after heating with electric pot

Kettle water : Tap water after heating with kettle

Table 3 The concentration $\left(\mathrm{ng} \cdot l^{-1}\right.$ ) of polynuclear aromatic hydrocarbons and their sum total in tap water collected from specific district in Tokyo Metropolitan during August 2004

\begin{tabular}{|c|c|c|c|c|c|c|c|c|c|c|}
\hline \multirow[b]{2}{*}{ PAHs } & \multirow[b]{2}{*}{ Shinjuku } & \multirow[b]{2}{*}{ Shibuya } & \multirow[b]{2}{*}{ Meguro } & \multirow[b]{2}{*}{ Hamamatutyo } & \multirow[b]{2}{*}{ Tokyo } & \multirow[b]{2}{*}{ Ueno } & \multirow[b]{2}{*}{ Tabata } & \multicolumn{3}{|c|}{ (Unit: ng $l^{-1}$ ) } \\
\hline & & & & & & & & Ikebukuro & Ochanomizu & Akabane \\
\hline Naphthalene & 9.99 & 19.33 & 16.46 & 7.97 & 2.00 & 1.73 & 1.39 & 27.66 & 4.01 & 2.83 \\
\hline Biphenyl & 8.73 & 7.73 & 5.39 & 8.47 & 6.85 & 2.67 & 2.84 & 7.59 & 6.20 & 6.32 \\
\hline Dibenzofuran & 60.47 & 51.59 & 40.22 & 46.70 & 46.70 & 27.75 & 25.94 & 59.83 & 54.52 & 55.91 \\
\hline Fluorene & 38.25 & 35.63 & 27.48 & 27.98 & 21.23 & 12.60 & 13.84 & 46.20 & 28.20 & 27.31 \\
\hline 9-Fluorenone & 50.87 & 40.74 & 45.34 & 38.94 & 34.55 & 23.38 & 25.41 & 47.97 & 39.09 & 53.70 \\
\hline Phenanthrene & 14.21 & 39.90 & 19.67 & 7.19 & 0.00 & 0.00 & 1.01 & 54.89 & 5.02 & 4.39 \\
\hline Antraquinone & 27.50 & 22.19 & 33.08 & 30.36 & 29.10 & 30.36 & 29.08 & 47.48 & 23.75 & 35.88 \\
\hline Fluoranthene & nd & 5.64 & nd & nd & nd & nd & nd & 5.37 & nd & nd \\
\hline Total PAHs & 210.40 & 223.15 & 187.95 & 168.04 & 140.69 & 98.50 & 99.50 & 296.98 & 161.26 & 186.32 \\
\hline
\end{tabular}

PAHs: polynuclear aromatic hydrocarbons nd: no detection 
トより強い加熱であるやかんで沸かした水道水中のビ フェニル, ベンゾフラン, フルオレン, 9-フルオレノン, アントラキノン濃度は更に減少していた。フルオレンは 残留塩素及び加熱により酸化され，9-フルオレノンにか わるので，最初にフルオレンは不検出になり，更に9-フ ルオンは電気ポットで減り，電気ポットより強い加熱で あるやかんで更に減少している。

Fig. 5, Fig. 6より，水道水を加熱する程，PAHs 自身 が減少し，またPAHs 酸化体である9-フルオレノン， アントラキノンも減少している傾向が認められた。

なお， 3 銘柄のミネラルウォーターを用いて，ミネラ ルウォーター中のPAHs も測定したが，全て不検出で あった。また，今回中空系膜付活性炭型浄水器を通した 水道水中のPAHs 濃度を調べていないが，活性炭は溶 存態のPAHs を吸着するので，吸着量が飽和に足して いなければ，水道水中のPAHs 濃度はかなり減少す $3^{17)}$ 。

\section{6 飲用するPAHs 恸取量}

水道水中の合計 PAHs 濃度は冬季で約 $10 \sim 30 \mathrm{ng} \cdot l^{-1}$, 夏季で約 $100 \sim 300 \mathrm{ng} \cdot l^{-1}$ であるので，1 日の合計 PAHs 摂取量は 1 日当り $2 l$ 飲用すると，冬季で約20６0ng， 夏季で約200～600ngになる。しかし，水道水を直接飲 用せず，通常沸かした水道水を飲用するので，沸かした 水道水を 1 日当り $1 l$ 领用すると仮定すると，合計 PAHs の掑取量は冬季で約15～45ng, 夏季で約150〜 450ngである。また：ミネラルウォーターを1日当り $1 l$ 飲用すると仮定すると，合計 PAHs の掑取量は冬季 で約10〜30ng，夏季で約100〜300ng になる。

今回検出したPAHsの内，フルオランテンはIARC で指定され，EPAで設定されている。また,ナフタレン， フルオレン，フェナントレン，ピレンはEPA で設定さ れている。これら PAHsの検出濃度から判断すると， 問題視されることはない。しかし，IARCで指定されず， EPA です設定されていないビフェニル，ジベンゾフラ ン，9-フルオレノンが水道水から検出しているが，これ ら PAHsの毒性評価は現在定まっていない。またこ れら PAHs は塩素処理 ${ }^{21 一 26)}$, 加熱により, 塩素化体, 酸化体に変化している。そして, PAHs 塩素化体は変異 原性が強まることが報告されている ${ }^{26-30)}$ 。今後，個々の PAHs 酸化体とPAHs 塩素化体，及びPAHs 全体の負 荷についての毒性評価が行われ，水道水の安全性が高め ることが望まれる。

\section{4.まとめ}

水中の PAHs 酸化体 4 種類を含めたPAHs29種類の ジクロロメタン抽出-GC/MS法の一斉分析法を確立し, この一斉分析法を用いて，分析を行った。

水道水中加検出されるPAHs は河川水と異なり， ジベンゾフラン，フルオレン，9-フルオレン，アントラ キノンの濃度が高かった。そして，浄水場近瀿の水道水 中の合計 PAHs 濃度は河川水(本流)中の合計 PAHs 濃 度に近かった。しかし，浄水場近隣に比へ，浄水場に遠 い水道水中の合計 PAHs 濃度は高かった。PAHs 濃度 が高い原因は水道本管の内面塗装剤，コールタール70\% 含有のタールエポキシ樹脂に起因していると考えられ る。
水道水中から検出したPAHs の内，濃度・検出頻度が 共に高いPAHsはジベンゾフラン，フルオレン，9-フ ルオレノン，アントラキノンであり，次ぎ濃度・検出 頻度が高いPAHsはナフタレン, ビフェニル，フェナ ントレンであり，これら PAHs 濃度は夏季に数十ng・ $l^{-1}$ で，冬季に数 $\mathrm{ng} \cdot l^{-1}$ であった。また，合計 PAHs 濃 度も，冬季で $10 \sim 30 \mathrm{ng} \cdot l^{-1}$, 春季で徐々に増加し, 夏季 で200～300ng $\cdot l^{-1} に な り ，$ 秋李で減少していた。この PAHs 濃度の季節変動は，水温(気温)に影響されている と考えられる。そこで，東京都特別区内の夏季の合計 PAHs 濃度を調查したところ，平均 $200 \mathrm{ng} \cdot l^{-1}$ であった。

水道水を加熱する程, 個々及び合計 PAHs, PAHs 酸 化体は減少している。1日当たりの合計 PAHs 捸取量 は水道水だけを $2 l$ 飲用すると冬季で約20６0ng，夏季 で約200 600ngになり，水道水 $1 l$ と沸かした水道水 $1 l$ を飲用すると冬李で約15４5ng，夏季で約150〜 $450 \mathrm{ng}$ となる。

謝 辞

投稿に当たり，都健康安全研究センターの水質研究科 長矢口久美子先生の御協力·援助に感謝申し上げる。

（原稿受付 2006年 8 月14日）

（原稿受理 2007年4月 9 日）

\section{参考文献}

1）指定疾病調查研究会 (松下秀鶴) (1978)昭和53年度指定疾病調 㚗，環境庁委託㱉務結果報告青，60-68.

2) Dipple, A. (1985) Polycyclic aromatic hydrocarbon carcinogenesis. ACS.Symp.Ser. (Am.Chem.Soc), 283-285.

3 ) Keith, L. H. (1997) Environmental endocrine disruters; A handbook of property data. John Wiley\&Sons.

4) Basu, D. K. and Saxena. J. (1978) Polynuclear aromatic hydrocarbon in selected U.S. drinking waters and their raw water sources, Environ. Sci. Technol., 12, 795-798.

$5)$ Sorrell, R. K., Brass, H. J. and Reding, R. (1980) A review of occurrences and treatment of polynuclear aromatic hydrocarbons in water, Environment International, 4, 245-254.

6) Herbert C. M., Willian j. B. and Ruby H. J. (1980) Investigation of potential water contamination by petroleum asphalt coatings in ductile-iron pipe, Proc Am. Water Works Assoc. Annu. Conf., 561-578.

7) Basu, D. K., Saxena, J., Stoss, F. W., Santodonato, J. and Neal, M. W. (1984) Water distribution system as a potential soruce of mutagens in drinking water, $\mathrm{PB}-85-125474$.

8 ) Shiraishi, H., Pllkington, N. H., Otsuki, A. and Fuwa, K. (1985) Occurrence of chlorinated polynuclear aromatic hydrocarbon in tap water, Environ. Sci. Technol., 19, 585-590.

9) Chang, E. E., Chang, S. C. and Chiang, P. C. (1995) Analyses of PAHs and mutagenicity in raw chlorinated water, Toxicol. Environ. Chem., 52, 177-189.

10) Lindley, E. (1997) Accounting for polycyclic aromatic hydrocarbons in public water supplies, Water Environ. Manag., 11, 119-125.

11) 環境庁環境保健部環境安全課(剣持堅志) (1999)多環芳香族炭 化水素類 $\left(\mathrm{PAH}_{\mathrm{S}}\right)$ 分析法, 平成 10 年度化学物質分析法開発調查 報告書, $1-71$

12) Hodgson, J. W., Bashe, W. J. and Baker, T. V. (1990) Determination of polyclic aromatic hydrocarbon in drinking water by liquid-liquid extraction and HPLC with coupled ultraviolet and fluorescence detection, EPA Method 550, 1-19.

13) Hodgson, J. W., Bashe, W. J. and Baker, T. V. (1990) Determination of polyclic aromatic hydrocarbon in drinking water by liquid-solid extraction and HPLC with coupled ultraviolet and 
fluorescence detection, EPA Method 550.1, 1-18.

14）日本水道協会：多環芳香族炭化水素( $\mathrm{PAHs}$ ) (2003) 上水試験 方法 2001年版, 505-511.

15）東京理科大学分析科学セミナー(小野寺祐夫) (1996) 新排水基 準とそれに対応する新処理技術(排水処理による溶存有機物の形 態変化とその分析法)，22-29.

16）梅谷友康，森実桂二(1999) 淀川水系に扔ける多環芳香族化合 物の濃度レベルと浄水処理特性，大阪市水道局水質試験所調査 研究ならびに試験成績，50，5-8.

17) 水道における未規制化学物筫等調查班 (主任研究者: 真柄泰基) (平成9-12年度) 2. 多環芳香族炭化水素，285-292.

18) Maier, M., Maier, D. and Lloyd, B. J. (1998) Mobilization of PAHs from the coal-tar lining of water mains as a result of disinfection, Water supply, 16, 211-219.

19) Maier, M., Lloyd, B. J. and Maier, D. (2000) Factors influencing the mobilisation of polycyclic aromatic hydrocarbon (PAHs) from the coal-tar lining of water mains, Water Res., 34, 773-786.

20）北原節子, 黑川公美子, 小川侑子, 田中和明（2005）アンケー 卜調查からみた扔いしい水及びその领用水質, 用水と廃水, 47, 378-383.

21) Lin, S., Lukasewycz, M. T. and Liukkonen, R. J. (1984) Facile incorporation of bromine into aromatic systems under conditions of water chlorination, Environ. Sci. Technol., 18 , 985-986.

22）高橋淳子，木村栄作，岩原繁雄，安藤正典，佐谷戸安好 (1984) 水中フルオランテンの塩素処理における挙動と変異原性, 衛生 化学, 30, 268-274
23）森康明, 内藤昭治, 後藤純雄, 松下秀鶴(1987) 水中ピレンの 塩素化反応によるモノクロロピレン及ざジタロロピレンの生成, 衛生化学, 33, 313-320.

24) Mori, Y., Goto, S., Onodera, S., Naito, S. and Matsushita, H, (1991) Aqueous chlorination of tetracyclic aromatic hydrocarbon, Reactivity and product disitribution, Chemosphere, 22, 495-501.

25) Mori, Y., Goto, S., Onodera, S., Naito, S., Matsushita, H. and Takitani, S. (1993) Changes in mutagenic properties and chemical fate of benz(a)anthracene in chlorine-treated water with and without bromide ion, Chemosphere, 27, 2155-2162.

26) Merkel T., Maier D., Maier M. and Sacher F. (1997) Reactions of polynuclear aromatic hydrocarbons with chlorine and chlorine dioxide in coal tar lined pipes, J. Water Supply, 46, 289-303.

27) Onodera, S., Igarashi, K., Fukuda, A., Ouchi, J. and Suzuki,S. (1994) Mutagenic potentials of anthracene and phenanthrene compounds during water disinfection with chlorine, Jpn. $J$. Toxicol. Environ. Health, 40(3), 233-243.

28) Johsen, S., Gribbestad, I. S. and Johansen, S. (1989) Formation of chlorinated PAH-A possible health hazard from water chlorination, Sci. Total Environ., 81, 231-238.

29) Basu, D. K., Saxena, J., Stoss, F. W., Santodonato, J. and Neal, M. W. (1984) Water distribution system as a potential sources of mutagens in drinking water, PB-85-125474.

30) Chang, E. E., Chang, S. C. and Chiang, P. C. (1995) Analyses of PAHs and mutagenicity in raw chlorinated water, Toxicol. Environ. Chem., 52, 177-189. 